\title{
SS-029 認知症との共生社会を支える基礎研究
}

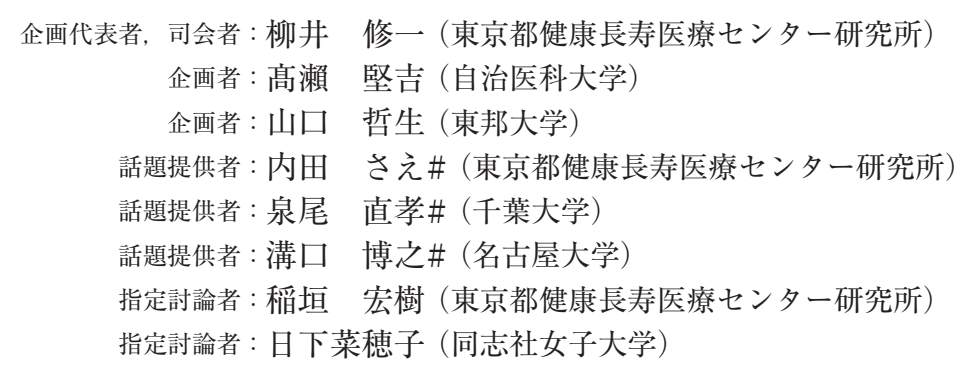

高齢者人口が増加し続ける我が国では, 2025年に認知症患者数が700万人前後に達すると推計されてい る。認知症予備軍である MCI を加えると, 高齢人口の 3 人に 1 人が認知症とその予備軍となる。認知症 は他の心因性, 器質性疾患と比較して「健康寿命ロス」が大きいことが知られている。認知症の対策は 医学的，社会的急務であり，認知症の発症を先送りすることで健康寿命口スを防ぐことが可能である。 超高齢化社会に扔ける認知症対策を考えるうえで, 認知症の発症メカニズム, また危険因子や防御因子 に対する理解が必要となる。本シンポジウムでは, 認知症とそれを取り巻く社会についての理解を深め るとともに, 認知症に対して基礎的観点からアプローチを行っている研究者に最新の研究成果を発表し ていただく。研究発表及びその後の議論を通じ, 「認知症との共生社会」を指向する動物実験の重要性に 加え，その社会還元性についての理解を深めることを目的とする。

一第1日 9 月25日(火) $15: 30 \sim 17: 30$

\section{SS-030 スポーツの眼, ロボットの眼, 武術の眼一視覚認知活動と身体 動作}

\author{
企画代表者, 司会者: 佐々木正晴 (弘前学院大学) \\ 話題提供者: 佐藤 佑介 (日本大学) \\ 話題提供者: 丹沢勉\# (山梨大学) \\ 話題提供者：下田 雄次（北東北 無形文化遺産実践研究協会) \\ 指定討論者：鳥居 修晃 (東京大学)
}

身体の各部位の活動・動作一たとえば, 跳ぶ, 歩く, 動きをかわす一に連動して対象を捉える視覚認 知活動は, それらを止めて対象を捉える場合の認知活動と, 同一には論じられない。本シンポジウムで は, 心理学では通常とりあげられない 3 つの研究領域の報告を承けて, 視覚認知活動と身体活動・動作 との関連性を考える。3 領域とは, 具体的には, 身体のダイナミックな動きが連続するスポーッ, 屋外 環境を安全, 円滑に移動しょうとするロボット, 他者/状況の動きを見定めて適確に対処する武術, で ある。これらの事態では, 動きながら対象を捉えたり, 動きのなかで自己と対象の位置を測ったり, 体 の行き先を方向づけたりする, 動作との連繋機能が求められるであろう。このような観点から, 3 領域 での若手研究者の研究報告を承けて, 開眼者, 脳損傷者, 先天盲に拄ける長期に渡る認知活動の形成・ 錬成過程を論考に加え，両者の関連性について総合的に考察を加える。 